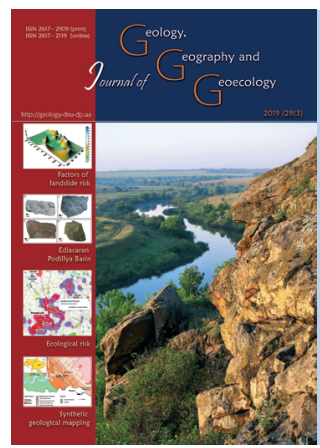

Journal of Geology.

ISSN 2617-2909 (print)

ISSN 2617-2119 (online)

Geography and

Geoecology

Journ.Geol.Geograph.

Geology,

28(3), 528-536.

Journal home page: geology-dnu-dp.ua

doi: $10.15421 / 111949$

O.V. Riabokon, L.V. Strashevska

Journ. Geol. Geograph. Geoecology, 28(3), 528-536.

\title{
Geological and geomorphological and historical components of the rock monasteries of the Middle Podnistrovia
}

\author{
O.V. Riabokon ${ }^{1}$, L.V. Strashevska² \\ ${ }^{1}$ Communal Higher Educational the Institution Vinnitsia Academy of Continuing Education, Vinnytsia, Ukraine, \\ olya_riabokon1986@ukr.net \\ ${ }^{2}$ Mykhailo Kotsiubynskyi Vinnitsa State Pedagogical University, Vinnytsia, Ukraine, strashevska_lv@ukr.net
}

Received: 03.01.2019

Received in revised form: 08.01.2019

Accepted: 21.03.2019

made. Nowadays, only three have remained and continue to be used for their original religious purpose: Bakota, Neporotovo, and Liadova cave monasteries. The place for foundation was not randomly chosen and was conditioned by several factors, the essential ones being geomorphological and sacred aspects. The geologic-geomorphologic factor was determined by presence of high and almost inaccessible rocks that allowed solitude and relative security for the inhabitants from raids of non-Christians. Not the last role belonged to the rocks, in which using simple tools, caves could be cut and rooms organized. It was determined that Bakota rock monastery was founded in opokas of Cenomanian stage, which were highly porous, and were malleable for processing. The tortuous route above the caves of the Bakota monastery was made in solid Sarmatian limestones along the denudation fractures widened by karst processes and by tools. Neporotovo cave monastery has mixed natural-anthropogenic origins and was initiated by karst-suffusion processes in the oolite Sarmatian limestones. Liadova cave monastery as well as Bakota cave monastery were cut from Cenomanian deposits, but in carbon facies, in which Cretaceous-like limestones dominate, which are malleable for making passageways Hydrogeological conditions were important for the building of the monastery, particularly, presence of drinking water. The sacred component was conditioned by religious canon laws and traditions. Each of the studied monasteries has a complex, and often tragic history recorded in archeological materials and archive documents, but the greater part of their thousand years history remains unknown.

Key words: rock monastery, Middle Podnistrovia, geological structure, lithogenic basis, geohistorical monuments

\section{Геолого-геоморфологічна та історична складові скельних монастирів Середнього Подністров'я}

О.В. Рябоконь ${ }^{1}$, Л.В. Страшевська ${ }^{2}$

${ }^{1}$ Комунальний вищий навчальний заклад “Вінницька академія неперервної освіти”, Вінниця, Україна, olya_riabokon1986@ukr.net

${ }^{2}$ Вінницький державний педагогічний університет імені Михайла Коиююбинського, Вінниця, Україна, strashevska_lv@ukr.net

Анотація. У представленій статті висловлюється припущення про закономірне поєднання літогенної основи і закладання скельних монастирів Середнього Подністров'я. Наслідком цього зв'язку є існування специфічних інтегрованих геоісторичних пам'яток (геосайтів). У прямовисних скелях каньйоноподібної долини Дністра з поширенням християнства стихійно закладались чисельні усамітнені чи колективні печерні обителі. Нині збереглися і продовжують функціонувати за призначенням лише три: Бакотський, Непоротівський та Лядовський скельні монастирі. Вибір місця для закладання монастиря був не випадковим і зумовлювався кількома факторами, серед яких ключова роль належала геолого-геоморфологічному та сакральному. Геологогеоморфологічний фактор визначався наявністю високих і важкодоступних скель, які давали можливість для усамітнення та відносної безпеки обителі при частих набігах іновірців. Не останню роль відігравали і гірські породи, в яких нехитрим ручним інструментом можна було прорубати келії і облаштувати відповідні приміщення. Встановлено, що Бакотський скель- 
ний монастир закладений у опоках сеноманського ярусу, які, будучи високопористими, легко піддаються обробці. Звивистий хід над печерами Бакотського монастиря прокладений у міцних вапняках сармату по денудаційним тріщинам, розширених карстовими процесами і людською рукою. Непоротівський скельний монастир має змішане натурально-антропогенне походження і зініційований карстово-суфозійними процесами в оолітових вапняках сармату. Лядовський скельний монастир, як і Бакотський, закладений у сеноманських відкладах, але у карбонатній фації, в якій домінують крейдоподібні вапняки, що податливі для прокладання штучних ходів. Важливе значення в монастирському будівництві мали гідрогеологічні умови, зокрема, наявність джерел питної води. Сакральна складова була зумовлена релігійними канонами і традиціями. Кожний 3 досліджених монастирів має свою складну й, нерідко, трагічну історію, зафіксовану в археологічних матеріалах та архівних документах, однак більша частина їх тисячолітньої історії залишається невідомою. У представленій статті висловлюється припущення про закономірне поєднання літогенної основи і закладання скельних монастирів Середнього Подністров'я. Наслідком цього зв'язку є існування специфічних інтегрованих геоісторичних пам'яток (геосайтів).

Ключові слова: скельний монастир, Середнє Подністров'я, геологічна будова, літогенна основа, геоісторичні пам'ятки

Introduction. The Middle Podnistrovia is rich in various natural geological monuments which owe their existence to the peculiarities of the geological structure of the region and favourable conditions for the outcrops of rocks created by the erosion activity of the Dnister river. Along with this, the Middle Podnistrovia was inhabited from ancient times by people who left a variety of items of material culture, many of which can now be regarded as archaeological, architectural, or other historical monuments. These monuments include rock monasteries located on the cliffs of both banks of the Dniester river.

The choice of location for future rock monasteries was not accidental and depended on a number of factors, not least among which was the geological factor. Therefore, there was a certain natural combination of natural and religious components. Therefore, the objective of the present study was a comprehensive natural and cultural-historical assessment of cave monasteries of the Middle Podnistrovia and the identification and analysis of patterns of this combination.

Materials and methods of research. From the geological point of view, the Middle Podnistrovia region has been studied quite fully and comprehensively, as evidenced by numerous publications (Geologicheskaya, 1982; Geologicheskaya, 1993; Denisik, 2014) on the stratigraphy of the Vendian, Cambrian, Ordovician, Silurian, Devonian, Cretaceous Neogene and Quaternary deposits, the study of various fossils and traces of life, paleogeography, the geomorphology of the river valley and the history of its formation. But the question of the combination of natural and historical components in the construction of cave monasteries has up to this time remained outside the field of view of scientists, which is obviously due to the highly specialized focus of these studies. A schematic and incomplete assessment of geological monuments is given in the guidebook "Geological Monuments of Ukraine" (Korotenko, 1985). More was expected from the official and authoritative, bright, well-illustrated multi-volume publication of the same name ,"Geological Monuments of Ukraine" (Bezvynnyy, 2006; Bezvynnyy, 2007). However, it does not mention rock monasteries at all. When giving recommedations on the protection of caves in Nahoriany village, mention was made only of the monastery in Liadova village, but without any description (Bezvynnyy, 2007, p. 25). Scant information about the cave monasteries of the region is scattered in separate special publications, the most wide ranging of which is "Cave Monasteries, Sketes and Cells in the World and Ukraine" (Dymytriy, 1995). The most complete, from the geological perspective, rock monasteries are described in the work "Rock Monasteries of the Middle Dniester as Complex Geological and Cultural-historical Monuments" (Korinnyy, 2008). A comprehensive approach to the study of natural monuments, such as cave monasteries and history, will allow us to more fully assess their scientific, educational, cognitive, aesthetic and recreational significance, as well as to find more rational and effective ways of protecting them.

Our main task was conducting a comprehensive study of rock monasteries, assessing the natural and cultural-historical components that influence their location, to develop recommendations for their further preservation .

Results and their analysis. In the middle flow of the Dniester river, the best preserved and the most famous are the Bakota, Neporotovo and Liadova male rock monasteries. Less well known and almost unexplored are the Sokiletsky and Subochskyi monasteries. There are also about a dozen caves or their remnants, the cultic purpose of which is clearly proven (Dymytriy, 1995; Ridush, 2001). It is unknown how many such structures were destroyed as a result of natural landslides, intentional or accidental human actions. Let us dwell on the natural and cultural-historical appraisal of those rock monasteries that can still be saved from further destruction.

Bakota St. Michael's Male Cave Monastery is $3 \mathrm{~km}$ west from the Goraivka village, Kamenets- 
Podilsky district of Khmelnytskyi Oblast in the Monastyrysky tract. The monastery is located in the middle of Bila Hora ( White Mountain ), a 120-meterhigh scarp which towers above the surface of the Bakota Bay of the Dniester reservoir. Bakota village itself, which in historical times was a thriving city the center of the Ponyzzia (Dniester Podillya) - and which gave the name of the monastery, is now gone. It disappeared under the waters of the reservoir.

From the geological perspective, Bila Hora is interesting in itself, as an outcrop, in which depositions of different age stratigraphic horizons are represented. The mountain itself, being part of the Dniester canyon, is a geomorphological monument.

From the shoreline, in ascending order, deposits of the Kanylivska Suite, the Molodovosky Horizon of the Ordovician, the Cenomanian and Sarmatian Stage of Cretaceous and Neogene can be seen as outcrops.

Deposits of the Kanylivska Suite are from the end of the Vendian stage of Podolia's geological development (Stratyhrafiya, 1971). However, on Bila Hora only the tops of the Suite reach the surface; the rest is flooded with water. The outcropped part of the Kanylivska Suite is composed of a thin layer of siltstones and schist argillites of greenish-grey, grey and dark-grey colours.

A subject of considerable interest is Ordovician deposits, which in Ukraine have outcrops only in this area. The Ordovician is represented by thin layers of the Molodovovsky Horizon: Horaivsky and Subitsky (Stratyhrafiya, 2013). The Horaivski layers are composed of grey quartzitic (over $90 \%$ of quartz) sandstones, which within Bila Hora have small and uneven thickness, often arise and disappear from the section. A similar bedding, as well as the presence of sandstone pebble in the bed of the overlying Subitski layers indicate an erosive break in the middle of the Molodovsky period. The Subitski layers are represented by grey limestones with a significant (up to $40 \%$ ) content of organogenic material, which includes segments of the crinoids, fragments of trilobites, bryozoans, ostracods and brachiopods. From the evidence of these fossils, it was found that the Molodovsky horizon belongs to the lower half of the upper division of the Ordovician system, and a stratigraphic break between the Ordovician and the Silurian in Podillia corresponds to the entire Ashgilian and almost entire Llandovery stages (Stratyhrafiya, 1972).

Deposits of the Cenomanian Stage are the most significant in the structure of Bila Hora. With a great stratigraphic mismatch, they are embedded on the eroded deposits of the Ordovician and have a very variegated lithological composition. These deposits begin with quartz-glauconite fine-grained sands, in which there occur occasional single sandy yellow primary phosphorites, phosphatized spicules of sponges, teeth of fish and other organic matter. The colour of the sands is green or yellow-green. Higher up, there are various rocks, the common feature of which is the high content of silica, which related to the fact that a large number of sponges with flint skeleton lived in the shallow Cenomanian Sea. Among such silicites, there are distinguished (Stratyhrafiya, 1971) flinted sandstones (gaizes), spongolites, opokas [Opoka (Polish) - silicic microporous sedimentary rock Translator 's note], chalcedonys, flint. Most significant among the Cenomanian Stage silicites of Bila Hora are the opokas which are clearly distinguished among others by a continuous several meter thickness. It was in such opokas that human hands almost a thousand years ago carved the cave-cells of the Orthodox rock monastery. The opokas of this place are characterized by light weight, high porosity and malleability in processing. They are light yellow or grey-white and consist of siliceous substances mixed with chalcedony, glauconite and quartz. Silicites are covered by glauconite-quartz sands with sandy yellow phosphates, phosphatized mollusc nuclei and traces of life of burrowing animals. The section of the Cenomanian Stage terminates with the boulder-like chalcedony stones with the foraminifera fauna.

Above the Cenomanian layer, a thick layer of limestones of the Sarmatian Stage of the Neogene is embedded. Limestones are represented by oolites and oolith-detritus and have a whitish-grey or yellowish colouration. The limestones are quite solid and form a high sheer wall below the peak with a slightly wavy surface and smoothed edges. Obviously, due to the bright colour of this sheer part, the whole mountain was named Bila (White). The limestone layers are broken by transverse fractures, in one of which a vertical spiral passage was made, which perhaps forms the upper level of the Bakota monastery.

In the Cenomonian horizon, springs of groundwater originate. Today there are three high flow springs which have long been considered to be healing. Laboratory analysis indicates that anions of chlorides and sulfates predominate in the water content. For example, in spring № 1, amount of chlorides was $27.25 \mathrm{mg} / \mathrm{l}$, sulfates $-46.50 \mathrm{mg} / \mathrm{l}$; the water is characterized by a weak alkaline reaction $(\mathrm{pH}$ equaled 7.30) and has a high level of hardness (8.6 $\mathrm{mEq} / \mathrm{l})$ (Korinny, 2008).

From the geomorphological perspective, the area around the monastery is also interesting, particularly 
the widened area of the Dniester canyon, where Bakota Bay formed when the Dniester was flooded. The bay with an area of about 850 ha has a horseshoelike shape with a bend towards the north. From the moment of its creation as a result of man-made activity, it has become a food base for a number of local birds and a place of rest for many migratory species. On its banks, rare shoreline-aquatic plant groups are distributed. Due to the uniqueness of the valley landscape, and also well as its important role in biodiversity conservation in 2004, Bakota Bay has been included in the List of Wetlands of International Importance, protected under the Ramsar Convention (Pryrodno-zapovidnyy).

It is impossible to overestimate the historicalcultural significance of this area. Before the flood, the territory was studied in detail by archaeologists. They discovered a number of ancient monuments (Davydenko, 2006). Thus, at the foot of Bila Hora, flint tools of the late Paleolithic were found. In the Monastirsky tract, the remnants of a large Trypillian settlement of the III-II centuries BC were studied. Not far from the present monastery, archaeologists investigated a large mound-like embankment with a stone ring in the center. It was determined that the structure was a sacrificial altar, erected in the late Bronze Age by the local agricultural community which worshiped the sun. In the vicinity of Bila Hora, remnants of Chernyakhiv culture have been found, which date back to the first half of the 1st century BC and the remains of early Slavic settlements.

The historical continuation of the ancient settlements was the ancient Rus town of Bakota, which was located on the site of the present Bakota Bay. In the territory of the ancient town, remains (Davydenko, 2006) of iron workshops, pottery and women's glass jewelry were found. According to the chronicle, during pre-Mongol times, Bakota was the center of social and political life, a significant strategic point of the Dniester Ponyzzia. In the radius of $15 \mathrm{~km}$ from Bakota, 31 settlements and 75 villages of the XI-XIII centuries were discovered. In Bakota, among other medieval attributes of a town, there was a feudal castle which was destroyed by the MongolTatars in 1258. At the top of Bila Hora archaeologists have found the remains of ancient earth ramparts and a large stone wall that surrounded the tract from the side of the field. After the defeat of the MongolTatars, the Lithuanian Koriatovich princes conquered the land. They rebuilt Bakota Castle, but as a result of the Polish-Lithuanian war, the castle was destroyed again, never to be rebuilt. Administrative functions passed first to Smotrych, and then to Kamyanets-
Podilsky. Since the second half of the XIV, century Bakota gradually lost the status of town, and since the XVI century was mentioned in documents only as a small village. In 1981, it was evacuated and flooded with the waters of the Dniester Reservoir (Horbnyak, 2004).

The creation of Bakota St. Michael's monastery is associated with the functioning of Bakota town, as one of the strongholds of the Galician Principality. The inscription on the wall indicates the consecration of the archangel Michael's monastery and the name of the founder and the first hegumen - Gregory. The palaeography of the inscription indicates (Horbnyak, 2004) that it was made not earlier than the mid-XII century. There is a version (Davydenko, 2006) that the monastery was founded even before the official recognition of Christianity as a state religion. In the mid-XIII century the monastery, simultaneously with the castle located on the mountain, was destroyed. It was rebuilt only a century later, but in the XV century it was ruined again and, due to the expansion of the power of Catholic Poland, the monastery ceased to exist. After the collapse of the rock, the central part of the monastic complex collapsed and became buried in debris.

In the $1980 \mathrm{~s}$ and $90 \mathrm{~s}$, the monastery was rediscovered by V. B. Antonovych, a well-known scientist, Ukrainophile, and a professor of the St. Vladimir University. The archeological expedition under his leadership (Antonovich, 1893) discovered the remnants of the monastery complex, which was on two levels. On the upper level, on the plateau of Bila Hora, in the Sarmatian limestones, a vertical spiral passage was cut with two small cells on the bottom. The connection between this room and the lower level has not been completely determined. The lower level was located approximately at the middle of the mountain. There, V. B. Antonovich discovered three cave buildings, described 17 niches in the walls and 19 tombs in the rock floor (Antonovich, 1886). Also unique frescoes, monastic items and weapons were found.

In 1893 a two-tier wooden church was erected over the remains of the old church with a high pent roof, which was consecrated under the name of the Savior. In 1960 it was destroyed (Davydenko, 2006).

Currently, the territory of the monastery is within the boundaries of the Podilsky Tovtry National Nature Park. By the efforts of the local religious communities and the Park staff the former church and the surrounding area has been brought into some kind of order. From time to time, the monument is visited by tourists, and occasionally religious services 
are conducted here. Despite the measures taken, this outstanding cultural-historical monument is threatened with extinction. Atmospheric factors are ruthlessly destroying the soft opoka rock and the overhanging rock may collapse at any moment. Taking into account the constant deficiency of government funds, the most appropriate solution, in our opinion, would be to give the remnains of the monastery to the Orthodox Eparchy. However, there is an idea, that building of a storage pool would slow the natural destruction of the monastery (Korinnyy, 2018). In such conditions, proper reconstruction could be made and therefore the Christian shrine preserved for generations to come.

St. Nicholas Neporotovo Male Monastery is located near Halytsia village, $2 \mathrm{~km}$ east of the Neporotovo village in Sokyriansky district of Chernivtsi Oblast. The monastery is located in a steep limestone cape formed by the right bank of the Dniester and the pre-mouth part of the right slope of the Halytsky gully at an altitude of 120 meters from the shoreline of the Dniester reservoir.

The cells of the monastery are located in oolitic limestones of the Sarmatian Stage of the Miocene. On fresh fracture, these limestones are pale yellow or greyish-white in colour and consist of small calcite oolites with additions of fine crushed shell detritus. Macro-palaeontological material appropriate for identification is found rare. Most often in the cores of oolytes, Foraminifera from the Quinqueloculina and Elphidium genera are found. Under the influence of atmospheric agents, the limestones have become darker and obtained grey tints.

But, obviously, the most interesting objects from the geological perspective are the elements of karst morphosculpture which can be clearly seen in the bare rocks of the monastery. According to morphology, two forms of morphosculpture can be distinguished: cavities and niches. Cavities are mostly oriented horizontally, which occurred due to their development along the areas of deposits, on which, due to the heterogeneity of the chemical composition of limestone interlayers, selective leaching of calcium carbonate has occurred. The cavities are characterized by fairly flattened walls and internal projections, which, obviously, can indicate the physical washingout of small underdeveloped particles. The sizes of the cavities range from a few millimeters to a meter or more.

Niches have karst-gravitational origin and have developed, on the one hand, due to the connection of cavities formed by leaching, and on the other hand by the collapse of the water-sharpened intersections between the caverns. Some niches formed from fractures in the structure of the Sarmatian deposits.

In the ancient times, natural niches were enlarged by people and were adapted for cells. Thus, the cave monastery near Halytsi village has a mixed naturalanthropogenic origin.

The original appearance of the karst morphosculpture can be imagined seeing the rocks in the Halytska Stinka (Galician Wall ) Landscape Reserve, which is located near the monastery, only on the opposite side of the Halytsky gully. There are the same karst cavities and niches, which sometimes turn into grottoes and small caves.

By contrast to the wooded Halytska Stinka, both of the rocky terraces of the monastery offer beautiful views of the surrounding countryside, the winding Dniester river, its canyon, the lowland peninsula formed by the meander of the Dniester, on which Neporotove village was built, which gave its name to the rock monastery.

The cultural and historical value of Neporotovo rock monastery is not yet fully determined. Exploring natural recesses in the rocks, archaeologists have found (Isachenko, 2006) traces of prehistoric man: animal bones, the remains of fires. In pre-Christian times, the recesses were used as pagan sanctuaries. In one of them, the remnants of a place of sacrifice were found, dated as early Iron Age.

The exact time when the Christian rock monastery emerged is not defined. It is supposed that it may have appeared at the turn of the XI-XII centuries.

Along the Dniester, apart from the main grouping of 20 caves near Halytsia, concentrated along a $1 \mathrm{~km}$ stretch, other groups of caves are located, which were also used as cult Christian structures. On a frieze of one of those caves located on the slope of the Galician ravine, unique and mysterious petroglyphs have been discovered, which have not been reliably identified (Isachenko, 2006). They look like some strange crosses, Greek letters, magic monograms, lines. The only thing that is not in doubt is their great antiquity.

There are very few written evidences of the functioning of the Neporotovo rock monastery as a religious structure. It is known only that before it was devastated by the Turks in the late XVIII century, it was known as the Galician Skete, where protesting monks found shelter. The monastery was restored only in 1904, and from the 1930s it was inhabited by monks, however not for long - the monks were expelled in 1948 when under the new (Soviet) government, and the monastery was desecrated and destroyed. The reconstruction began in 1999, and now it is a unique, fully completed rock-cave naturalarchitectural complex. 
Liadova Saint Useknovensky Male Rock Monastery was located on the south-western edge of Liadova village in the Mohyliv-Podilskyi district of Vinnytsia Oblast. The monastery was located on the left bank of the Dniester river, $0.5 \mathrm{~km}$ below the mouth of the Liadova river. The rock, from which the monastery was been cut, and which locals since the old times have called the Tserkovna Hora (Church Mountain), as well as the surrounding area, has great geological and cultural-historical significance .

The geological structure of Tserkovna Hora is best seen in the Church Ravine, which crosses the path to the monastery. A small bridge across the gully was constructed, allowing pilgrims to reach the holy places without hindrance. In the Church Ravine, if one walks to the top along the thalweg, great outcrops of the Vendian Cretaceous and Neogene systems can be seen.

The Vendian deposits are represented there by the Nahorynska Suite formed by the Dzhurdzhivk and Kaliusk layers (Stratyhrafiya, 1971). The Church Ravine is part of the stratotypic section of the Nagoriany Suite. Further on, this section passes the mouth of the Liadova and stretches on to Nahoriany village.

The Dzhurdzhivk layers of the Nagoriany gully are composed of alternation of fine-grained thin sandstones and argillites. Sandstones of these layers often contain fine interlayers of aleurolites and argillites and have mostly grey colours with barely noticeable notable green tint in fresh fractures. The argilites often contain interlayers of aleurolite and fine-grained sandstones and are mostly of green-grey colour.

The Kaluski layers are predominantly composed of mostly motley-coloured, thin argillites which, without much effort, are easily shattered to small sharp-edged fragments. A notable feature of the Kaluski layers is their content of phosphorites. Due to this peculiarity, the Kaliuski layers are a marking horizon. In the Church Ravine, there are single phosphorite concretions that have a spherical or rounded shape and a scabrous surface. In the middle, such concretions have a radial structure and an internal cavity that is often filled with calcite, galena, chalcopyrite, etc.

The total thickness of the Nahorianska Suite in the gully reaches about $40 \mathrm{~m}$. The analysis of the lithological composition of the Suite allows us to determine the conditions in which the rock was formed. Taking into account the signs of folds, oblique lamination, the presence of glauconite in sandstones of the Dzhurdzhivki Layers, it can be stated that it developed in conditions of shallow water marine basin.. By contrast, the Kaliuski Beds formed in conditions of deeper waters. This is indicated by the thin lamination of clay rocks and insignificant content of sand and aleurite fractions in them. It is quite possible that over the Kalusky period, the marine basin in Podilly had obstructed water exchange with the ocean and experienced hydrogen sulfide contamination (Stratyhrafiya, 1971).

The Cretaceous system in the Church Ravine is represented by sediments of the Cenomanian Stage. They are embedded on the significantly eroded surface of the Kaluski layers, forming stratigraphic non-uniformity with a break of about 500 million years . The base the Cenomanian Stage is composed of a layer (almost $1 \mathrm{~m}$ ) of dark green glauconitic sand with pebbles of rounded phosphorites and Vendian sanstones. Deposits of secondary phosphorites , which were washed out from the Kaliuski layers and re-deposited on the bed of the Cenomanian sea, were confined to this layer.

Unlike Bila Hora, the Cenomanian Stage in this locality is represented not by flint facies, but by the carbonate facies, in which are Cretaceous limestones dominate. These rocks are characterized by white or light grey colour and are $80-90 \%$ composed of calcite; the rest is globular silica (5-8\%), clayey substance (up to 5\%), aleurite grains, etc. (Stratyhrafiya, 1971). In the layers of Cretaceous limestones there are numerous concretions of spotted, black and grey flints, and opoka-type silicites. Less commonly, there are flinted traces of digging animals, skeletal remains of foraminiferans, small spicules of sponges and other faunal remains. Limestones are easily malleable, which allowed the caves of the Liadova rock monastery to be carved here in medieval times.

The Cenomanian Stage terminates with a thick (up to $10 \mathrm{~m}$ ) layer of various flints covered with white crust, consisting of a mixture of calcite and chalcedony. The intervals between the flints are filled with a limey substance. Chaotic accumulation of flints in the layer allows one to conclude that a partial pre-Sarmatian wash-out of limestones occurred, out of which only flints have remained.

The Neogene deposits are composed of the Lower Sarmatian rocks, which in the Church Ravine has a rather mottled lithological composition. The lower layers are mainly represented by alternation of clayey quartzitic sands and sandy clays, in which typical Sarmatian forms of molluscs, including Ervilia podolica, occur. In the upper part of the Lower Sarmatian substage, sandy ooliths and limestone with shells dominate. The latter are much more solid and 
often form cornices. At the top of the gully, a washedout area of the The Sarmatian layer can be seen, into which the delluvial Quaternary loams are washed . They have a brownish colour and are slightly reminiscent of loess. Perhaps the modern Podnistrovia loess-free area is a consequence of the erosion of loess layers. In the loams, there are large amounts of well-rounded pebbles, in which grey-brownish and red jaspers dominate. These rocks are alien to this area and there is an opinion (Vyrzhikovskiy, 1926.) that they are of Carpathian origin.

Hydrogeological features of Church Ravine are also interesting. In the territory of the Liadova Monastery there are two powerful springs which originate in the Cenomanian water-bearing horizon. The lower spring is called Anthonieve and is especially revered by the people for its healing properties. It has been determined that these properties are conditioned by the significant saturation of water by silicon and a specific cationic-anionic composition. According to the classification it is a natural table water of hydrocarbonate-sodium-calcium-magnesium composition. Its $\mathrm{pP}$ is 7.11 , hardness $-6.7 \mathrm{mg}$-ekv / 1 , total mineralization $-0.4-0.8 \mathrm{~g} / 1$.

The area around the monastery has a significant geomorphological value and is very picturesque. From the height of Tserkovna Hora, one can see a magnificent view of the Dniester, its gigantic loop that envelops the shallow shore of Moldova. Then on the left and to the right up to the horizon, there can be seen the heights of Bessarabsky and Podilsky plateaus. From this place, one can clearly observe that both plateaus are really one integrated plateau which, as if accidentally, is cut by the valley of the Dniester. On the other hand, this landscape clearly demonstrates the results of the grandiose geological activity of the great river.

The left, Ukrainian, bank of the Dniester is steep and rocky. In its white limestones, black entrances to the Nahorianski karst caves are seen. Closer to the observer, the solid rocky shore is interrupted by the winding valley of the Liadova. In this place, a wide alluvial valley is located, deeply cut into the shore. The valley was formed by alluvia of the Liadova river. The steep slopes around the plain form a high rocky amphitheater with numerous steep gullies which are whitened by their limestone internal parts.

The scientific and scientific-educational value of this territory can be indicated at least by the fact that out of the 21 geological relics recorded in Vinnitsa Oblast (Korotenko, 1985), three of them are within a radius of $1-1.5 \mathrm{~km}$ from the monastery, in particular an outcrop of the Cenomanian deposits near the Liadova village, stratotype of the Nagoryany Suite and caves in Nahoriany village. It should be mentioned that old (from the 1870s) mining works for the extraction of concretionary phosphorites remain completely unexplored ( Korinnyy, 2016). Adits are arranged along both slopes of the Liadova, and some of them, according to the locals, are 500 or more meters deep in the rocks.

Compared to other cave monasteries, the culturalhistorical significance of the Liadova Monastery seems to be better explored, especially after the publication of a book V.V. Davydenko "Monastery" (Davydenko 2006). In this, without exaggeration, fundamental study, the author not only covered the historical assessment of the Liadova monastery, but also deeply analyzes the socio-political situation at a particular time which determined the fate of both the monastery itself and the fate of our people.

The relatively good state of knowledge about the Liadova monastery is evidently conditioned by its millennial history, which did not experienced long interruptions.

The territory where Liadova monastery is located has been used by man since Paleolithic times. This is evidenced by the numerous findings of stone tools near the mouth of the Liadova and the Nahoriansky caves. Perhaps, the cavemen occupied part of the Liadova caves (the other part has an artificial origin).

Other interesting and unique objects are the megalithic constructions with mysterious petroglyphs, located near the caves on the slopes of Nagorianski rocks. They astonished researchers in the XIX century, but since that time they have not been seriously studied. Similarly to megaliths in other countries, they probably belong to the Neolithic or Bronze Age.Their cultic purpose is quite obvious. According to the scattered findings of sculptures of pagan deities, there was also a pagan sanctuary on the top of the Tserkovna Hora (Davydenko, 2006) in preChristian times.

In the XI century, the Christian era of the development of the Liadova rocks began. According to the legend (Dymytriy, 1995), in 1013 Anthony of the Caves, the founder of the Orthodox monasticism in Rus, on his way back along the Dniester from Mount Athos, where he took his monastic vows, to Kiev, carved a cell in the maleable limestone; there he lived for some time and preaching Christianity among the Tivertsi. Over time, like-minded people joined him. This led to creation of the Liadova male monastery. There is also another version (Davydenko, 2006) according to which the Christian monastic caves in the Liadova rocks existed long before Anthony 
arrived there and even before the emergence of the Kievan Rus itself. It is believed that the Dniester was a kind of bridgehead, from where Christianity tore its way to the east.

The first written mentions of the monastery date back to 1159. Since that time, all the vicissitudes of history have been reflected in the monastery's fate: feuds between princes, Mongol-Tatar rule, Lithuanian rule, Polish oppression, Tatar raids, Russian and Soviet times. More than once, the Liadova monastery became a kind of regional center of Cossack resistance and actively participated in peasant unrest . During the long period of its existence, the monastery has lived through periods of flourishing and decline. The prosperity was related to the well-known Liadova trade fairs held at the foot of the Tserkovna Hora, and where various goods from all over Podolia, Bessarabia and adjoining territories were brought. Certainly, the participants of the fair gave generous donations to the working churches. Since the late XVII century on the northern wall of the monastery, eminent guests of the monastery have left their autographs in different languages.

Since its foundation, the monastery has been repeatedly destroyed and devastated. Yes, obviously, the greatest damage was caused by an explosion set off by the Soviet authorities in 1938. However, after 10 years the ruins of the monastery became a state monument of architecture of the XI-XIX centuries. Now the remnains of the monastery are given to the Orthodox community willing to reconstruct it.

Even this rather superficial assessment of the geological and historical constituents of the described monuments demonstrates a number of regularities.

A place for a cave monastery was chosen on a mountain or in a high rock. This is due to several reasons. The first of them is probably a pagan tradition, according to which praying on high mountains brought you closer to the sky. That is why the idols, for example, to Perun or Sviativod, were placed on high hills. The proof of the borrowing of this custom is that in many cases Christian churches were placed on the site of ancient pagan temples.

Important for the emergence of cave monasteries was the early Christian tradition about the birth of Jesus Christ in Bethlehem Cave, which became the place of forgiveness of all Christians of the world. Therefore, Christian cave monasteries are found not only in Podillia, but also in the Crimea, near Jerusalem, in Greece, Italy, Bulgaria, Turkey (Cappadocia), Georgia, and elsewhere (Dymytriy, 1995). Another reason for the cave tradition was the persecution of the first Christians by adherents of different faiths, so they were forced to hide in inaccessible and protected places. Perhaps this is why the first Christian monasteries in Podillia and in Rus were cave monasteries. With the establishment of Christianity and with the development of the monastries, they became terrestrial cultic structures. For example, one can mention the Kyiv-Pechersk Lavra, the Holy Trinity Monastery near Satanov, etc.

Another aspect of the choice of site is lithological. Not just any high and inaccessible rock was chosen for a monastery, but a rock with natural (karst) hollows in it, which by additional processing could be made into monastic cells. If such were absent, suitable sites for foundation of a monastery were soft rocks, in which an artificial cave could be cut using primitive tools. That is, the rocks should have property of karsting (as in the case of the Neporotovo and Liadova monasteries), or be easily malleable (rocks of the Bakota and Liadova monasteries).

Hydrogeological conditions were also important for the construction of the monastery in particular, the accessability of sources of drinking water, which would not only assauge the thirst of the monks themselves, but also had an important "economic" role. After the monastery had been created, such springs became holy and were credited with healing properties. They contributed to the increase in the number of pilgrims, thanks to whose donations the monasteries existed.

However, no matter how important natural factors may seem to us, historical factors were determining. In the Middle Ages, the Dniester was an important trade route. At that time, the Dniester itself and its tributaries were deeper, providing unhindered passage to the merchant ships with grain, honey, craft goods, etc. Obviously, the first Christians appeared in mass along this route, as well as the cave monasteries, spreading the Christian faith.

Conclusions. The emergence of rock monasteries in the Middle Podniestrovie is conditioned by historical factors and favourable geological conditions for their establishment . A combination of religious (historical) and natural (geological) components are quite clearly seen on the example of Neporotovo, Bakota and Liadova rock monasteries. Such combination is conditioned by religious tradition and engineeringgeological conditions of construction. The main factors which provided a combination of both components are: 1) high position of a monastery above the surrounding lowland; 2) provision of a minimum level of security for the monks; 3 ) presence of natural recesses or softness of rock; 4) availability of drinking water sources. Therefore, the locations of 
the cave monasteries are often related to geological relics, forming integrated geohistorical attractions geosites.

\section{References}

Antonovich V.B. 1886. O skal'nykh peshcherakh na beregu Dnestra [On rocky caves on the bank of the Dniester]. Proceedings of the 6th Archaeological Congress, 1, 87-102 (in Russian).

Antonovich V.B. 1893. Dopolnitel'nyye raskopki v Bakotskom skal'nom monastyre [Additional excavations in the Bakotsky rock monastery]. Readings in the historical society of the chronicler. Nestor, 7, 17 18. (in Russian).

Bezvynnyy V.P., Bilets'kyy S.V., Bobrov O.B. 2006. Heolohichni pam"yatky Ukrayiny. U 4-kh tt.

T. I: Karpat·s'kyy rehion i Volyno-Podillya [Geological sites of Ukraine]. V.I. Kalinin. DIA, Kyiv (in Ukrainian).

Bezvynnyy V.P., Bobrov O.B., Bryans'kyy V.P. 2007. Heolohichni pam"yatky Ukrayiny. U 4-kh tt. T. II: Ukrayins'kyy shchyt [Geological sites of Ukraine] V.I. Kalinin, D.S. Gursky. Kyiv (in Ukrainian).

Davydenko V.V. 2006. Monastyr [Monastery] DP «Derzhavna kartohrafichna fabryka», Vinnytsya (in Ukraine).

Denisik G.I., Strashevskaja L.V., Korinnuy V.I. 2014. Geosites Podolia. [Geosites Podolia]. Vinnyts'ka oblasna drukarnya, Vinnytsya (in Ukrainian).

Dymytriy, 1995. Pecherni monastyri, skyty ta keliyi u sviti y Ukrayini [Cave Monasteries, Sketes and Cells in the World and Ukraine]. Osnova. 6, 118-134 (in Ukrainian).

Geologicheskaya istoriya territorii Ukrainy: paleozoy. 1993. [Geological history of the territory of Ukraine: Paleozoic] Tsegelnyuk. Naukova Dumka, Kyiv (in Russian).

Geologicheskaya izuchennost' SSSR. 1982. [Geological study of the USSR] Tom 32: Ukrainian SSR (Central and Eastern regions, period X: 19661970), 1. Naukova Dumka, Kyiv (in Russian).

Horbnyak T. 2004. Bakota - zatoplena dolya [Bakota - flooded fate]. Podillya, Khmel'nyts'kyy (in Ukraine).

Isachenko S. 2006. Zvezdy nad monasheskim skitom. [Stars over the monastic skete]. Mirror of the week 45 (624) (in Russian).

Korinnyy V.I. Strashevs'ka L.V., 2016. Shtol'ni z vydobutku fosforytiv na Podilli yak potentsiyni hirnycho-promyslovi geosayty. [Adits for the extraction of phosphorites in Podillya as potential mining-industrial geosites]. Scientific notes of the Mykhailo Kotsiubynsky Vinnitsa State Pedagogi- cal University. Series: Geography, 28 (3-4), 45-51 (in Ukrainian).

Korinnyy V.I., 2018. Dnistrovs'ke vodoskhovyshche yak spovil'nyuvach pryrodnoho ruynuvannya Bakot·s'koho skel'noho monastyrya. [Dnistrovsky reservoir as a moderator of the natural destruction of the Bakotsky rock monastery]. Collection of materials of All-Ukrainian Round Table of Methodologists, Scientific Leaders of Department of Sciences dealing with Earth Sciences of MAH of Ukraine. Kyiv (in Ukrainian).

Korinnyy V.I., Strashevs'ka L.V., 2008. Skel'ni monastyri Seredn'oho Podnistrov'ya yak kompleksni heolohichni ta kul'turno-istorychni pam'yatky. [Rock monasteries of the Middle Dniester as complex geological and cultural-historical monuments]. Scientific notes of the Mykhailo Kotsiubynsky Vinnitsa State Pedagogical University. Series: Geography, 16, 114-123 (in Ukrainian).

Korotenko N.E, Shchiritsa A.S., Kanevskiy A.Y. 1985 Geologicheskiye pamyatniki Ukrainy: Spravochnikputevoditel' [Geological Monuments of Ukraine]. Naukova Dumka, Kyiv (in Russian).

Pryrodno-zapovidnyy fond Ukrayiny [Natural Reserve Fund of Ukraine]. [Electronic resource]. Access mode: http://pzf.menr.gov.ua. - Title from the main web page.(in Ukrainian).

Ridush B., 2001. Poshyrennya pechernykh monastyriv u Seredn'omu Podnistrov"yi [Distribution of Cave Monasteries in the Middle Podnistrovia]. International Scientific Congress «Ukrainian Historical Science at the Turn of the XXI Century». 3, 380387 (in Ukrainian).

Stratyhrafiya URSR. 1971. [Stratigraphy of the USSR]. 2: Riphean-Vendian. O.V. Krasheninnikova. Naukova Dumka, Kyiv (in Russian).

Stratyhrafiya URSR. 1971. [Stratigraphy of the USSR]. 8: Cretaceous. O.K. Kaptarenko-Chernousova. Naukova Dumka, Kyiv (in Russian).

Stratyhrafiya URSR. 1972. [Stratigraphy of the USSR]. 3: Cambrian, Ordovician. P.L. Shul'ha. Naukova Dumka, Kyiv (in Russian).

Stratyhrafiya verkhn'oho proterozoyu ta paleozoyu Ukrayiny. 2013. [Stratigraphy Upper Proterozoic and Phanerozoic by the Ukraine] V. 1: Stratigraphy Upper Proterozoic, Phanerozoic and Mesozoic by the Ukraine. P.F. Gorzyk. Logos, Kyiv (in Ukrainian).

Vinokur I. Khotyun H. 1967. Rozkopky Bakoty [Excavations Bakota]. Science and society, 6, 1213. (in Russian).

Vyrzhikovskiy R. 1926. Geologicheskiy putevoditel' po Zapadnoy Podolii [Geological guide-book to Western Podillya]. Kyiv (in Russian). 